\title{
Decitabine and Cisplatin are Synergistic to Exert Anti-Tumor Effect on Gastric Cancer via Inducing Sox2 DNA Demethylation
}

This article was published in the following Dove Press journal: OncoTargets and Therapy

\author{
Zhipeng Zhu' \\ Sihao Lin' \\ Xiaofang $\mathrm{Wu}^{2}$ \\ Jiuhua $X u^{2}$ \\ Lulu $\mathrm{Li}^{1}$ \\ Weipeng $\mathrm{Ye}^{2}$ \\ Jiayi $\mathrm{Li}^{3}$ \\ Zhengjie Huang ${ }^{1,2}$ \\ 'Department of Gastrointestinal Surgery, \\ Xiamen Cancer Center, The First \\ Affiliated Hospital of Xiamen University, \\ Xiamen, Fujian 361003, People's Republic \\ of China; ${ }^{2}$ Department of Clinical \\ Medicine, Fujian Medical University, \\ Fuzhou, Fujian 350004, People's Republic \\ of China; ${ }^{3}$ Department of Medical \\ Oncology, Xiamen Cancer center, The \\ First Affiliated Hospital of Xiamen \\ University, Xiamen, Fujian 361003, \\ People's Republic of China
}

Background: Cisplatin is a vital chemotherapy regimen for gastric cancer (GC), while partial response is observed (approximately 40\%) because of drug resistance. Thus, it is urgent to improve drug sensitivity to improve the therapeutic effect of cisplatin on GC.

Purpose: The study was performed to explore the synergistic effect of decitabine and cisplatin in GC.

Materials and Methods: Cancer and matched adjacent tissues from patients with GC were obtained and quantitative real-time PCR (qRT-PCR), Western blot and immunohistochemistry were performed to evaluate Sox 2 expression level. Methylation-specific PCR (MSP) was performed to assess the effect of 5-aza-2'-deoxycytidine (5-Aza-CdR) on Sox 2 promoter. Cell proliferation assay, scratch-wound migration assay and Transwell invasion ability were performed to assess the effect of 5-Aza-CdR on proliferation, migration and invasion ability. Meantime, the effect of 5-Aza-CdR was also investigated in gastric cell lines BGC-823 and nude mouse xenograft tumor model. Finally, the anti-cancer effect of decitabine, cisplatin and their combination treatment were investigated in a BGC-823 and nude mouse xenograft tumor model, Sox 2 methylation level, Sox2 expression of BGC-823 and xenograft tumors were analyzed by MSP, qRT-PCR and Western blot.

Results: Sox 2 expression was significantly associated with different differentiated degrees, depth of invasion (0.0011), lymph node metastasis (0.0013), and TNM stage (0.0002). Next, methylation inhibitor 5-Aza-CdR restored Sox2 expression to promote proliferation, migration and invasion in vitro and in vivo. Finally, cisplatin and decitabine was found to be synergistic to inhibit proliferation of xenograft tumors. Likewise, cisplatin and decitabine were also synergistic to induce Sox2 DNA demethylation to promote Sox 2 mRNA and protein expression in BGC-823 and xenograft tumors.

Conclusion: Cisplatin and decitabine could be synergistic to induce Sox2 DNA demethylation to promote expression of the Sox 2 gene, which exerted an anti-tumor effect on GC. It may suggest an insight for innovative therapeutics of GC.

Keywords: Sox2, DNA demethylation, gastric cancer, decitabine, cisplatin, anti-tumor

\section{Introduction}

GC is one the most commonly occurring gastrointestinal tumors, which has remained the second leading cause of cancer-related mortality over the past few years. ${ }^{1}$ Multiple risk factors participate in the emergence and development of GC, including environmental factors, genetic factors, and epigenetic alterations. $^{2}$ Briefly, epigenetic alterations could regulate gene expression without changes in DNA sequence, which lead to genetic changes in various tumor
Correspondence: Zhengjie Huang Dastrointestinal Surgery, Xiamen Cancer Center, The First Affiliated Hospital of Xiamen University, 55 Zhen Hai Road, Si Ming District, Xiamen, Fujian 361003, People's Republic of China

Tel +86-592-2139280

Fax +86-592-2137368

Email huangzhengjie@xmu.edu.cn 
oncogenes and suppressor genes. ${ }^{3}$ As the main mechanisms in epigenetic regulations, DNA methylation plays an important role in cell biology, gene silencing and embryonic development, and aberrant DNA methylation participates in the initiation and progression in various cancers. $^{4}$

An analysis involving 15 types of cancers from 600 samples indicated that aberrant DNA methylation appears on various types of cancer-related genes with different frequencies of different cancer-related genes in different parts. ${ }^{5,6}$ Hypermethylation is a prompter of suppressor genes which can reduce genes silencing, such as CDH13, p16, MGMT, and E-cadherin. And hypermethylation status in several tumor suppressor genes may be the early driver event in GC, including E-cadherin, Runx3 (runt-related transcription factor 3 gene), CHFR, and DAPK.

It was known that Sox 2 is significantly associated with differentiation, initiation, progression and malignant biological behavior in the gastrointestinal tract. ${ }^{7-9}$ Previous studies revealed that Sox 2 is up-regulated in gastric cancer cells ${ }^{9}$ and gastric stem cells, ${ }^{10}$ which function as oncogene to promote the occurrence and development of GC, and Sox 2 overexpression is associated with poor prognosis. ${ }^{11}$ However, more studies showed Sox 2 could be considered as a tumor suppressor gene, which plays a vital role in anti-cell proliferation, anti-metastasis, and antiapoptosis. $^{7,12-15}$ Patients with positive Sox2 expression have longer overall survival than patients with negative Sox 2 expression. ${ }^{13,16}$ Furthermore, Sox 2 protein expression may be considered as an independent prognostic factor for survival prognosis in GC. ${ }^{17}$

Chemotherapy is still the main therapeutic regimen in polychemotherapy to treat advanced gastric cancer. With wide application of Cisplatin, Irinotecan, Taxus, 5-fluorouracil and so on, the effect of chemotherapy has been remarkably improved. However, a considerable proportion of patients cannot benefit from chemotherapy because of drug-resistance. Cisplatin is a cell cycle related nonspecific cytotoxic drug, which can inhibit the DNA replication process and damage their cell membrane structure, and it is effective in malignant tumors from various systems, organs and tissue sources. Cisplatin and its derivant account for $70 \%$ of chemotherapy regimens, ${ }^{18}$ which is frequently applied in polychemotherapy regimens in $\mathrm{GC}$, while partial response is observed only in approximately $40 \%$ because of drug-resistance. ${ }^{19}$ Thus it is urgent to improve drug-sensitivity to improve the therapeutic effect of chemotherapy on GC.
Recently, the association between tumor resistance and methylation as a prompter has become a hot topic. It is known that DNA methylation is a reversible process and DNA methyltransferase (DNMT) is the most important molecule to restore the function of tumor suppressor genes, including DNMT1, DNMT2, and DNMT3. DNMT1 is closely associated with cancers. ${ }^{20}$ Nowadays, decitabine is the representative drug belonging to DNMT1 inhibitor, which was firstly approved to treat myelodysplastic syndrome by FDA, ${ }^{21}$ the clinical significance for solid tumor, such as lung cancer ${ }^{22}$ and prostate cancer. ${ }^{23}$ Viet et $\mathrm{al}^{24}$ revealed decitabine could resduce cisplatin resistance in head and neck squamous cell carcinoma, which indicated DNA methylation may be considered as a biomarker of cisplatin resistance. However, few studies have reported the synergistic effect of decitabine and cisplatin in GC.

\section{Materials and Methods}

\section{Clinical Tissue Samples, Cell Lines and Animals}

Gastric cancer and matched adjacent tissues were obtained from the Department of Gastrointestinal Surgery, The First Affiliated Hospital of Xiamen University, the People's Republic of China, between September 2010 and February 2016. All samples were collected with patients' informed consent, and all tissues were pathology confirmed. This study was approved by the Ethics Committee of the First Affiliated Hospital of Xiamen University.

The gastric cell lines BGC-823 and GES-1 were provided by the Department of Cancer Center, The First Affiliated of Xiamen University (Xiamen, People's Republic of China). All cells were cultured in RPMI1640 medium containing 10\% heat-inactivated fetal bovine serum (FBS) and maintained at $37^{\circ} \mathrm{C}$ in a humidified chamber containing $5 \% \mathrm{CO}_{2}$.

The animals consisted of $72 \mathrm{BALB} / \mathrm{c}-\mathrm{nu} / \mathrm{nu}$ nude mice (4 weeks, 20-25 g) and were obtained from Xiamen University Laboratory Animal Center.

\section{Quantitative RT-PCR (qRT-PCR)}

Total RNA was extracted using TRIzol reagent (Invitrogen; Thermo Fisher Scientific, Inc.) after tissue samples and cell lines were harvested. cDNA was synthesized using ReverTra AceH qPCR RT Kit (TOYOBO) with $1 \mathrm{mg}$ total RNA. The primer upstream sequence of 
Sox2 was 5'-ATGGGTTCGGTGGTCAAGTC $-3^{\prime}$ and the primer downstream sequence was $5^{\prime}$-CCCTCCCAT TTCCCTCGTTT $-3^{\prime}$. The primer upstream sequence of GAPDH was 5'- GTGGACCTGACCTGCCGTCT -3' and the primer downstream sequence was $5^{\prime}$ GGAGGAGTGGGTGTCGCTGT -3'. Quantitative RTPCR was performed for 30 cycles of denaturation (at $94^{\circ} \mathrm{C}$ for 30 seconds), annealing (at $56^{\circ} \mathrm{C}$ for 30 seconds) and elongation (at $72^{\circ} \mathrm{C}$ for 1 minute).

\section{Western Blot}

Western blot was performed as described previously. The primary antibodies were anti-Sox 2 antibody and antiGAPDH antibody, and goat anti-mouse/rabbit double antibodies were used as secondary antibodies.

\section{Immunohistochemical Staining}

Immunohistochemistry analysis was conducted as described previously. After deparaffinizing and rehydration, immunostaining was performed at $4{ }^{\circ} \mathrm{C}$ overnight with anti-Sox 2 antibody and peroxidase-conjugated antimouse secondary antibody. Then, streptomycin antibiotic protein-peroxidase was added into incubator at $37^{\circ} \mathrm{C}$ for 45 minute. Next, DAB chromogenic fluid was used to perform chromogrnic reaction. Following hematoxylin dye solution for redyeing, gradient alcohol for dehydration, dimethylbenzene for vitrifying and neutral gum for depositing.

\section{Methylation-Specific PCR}

Genomic DNA was extracted from cell lines and translated tumor using TIANamp Genomic DNA kit, DP304. The MethPrimer website (https://www.urogene.org/methprimer/ index1.html) was performed to identify $\mathrm{CpG}$ islands of Sox2, The methylated primers were 5'-AGTCGTCGGGTTCGT AGTAAATTTC -3' (sense), 5'-AAAACATTCATAAACC GCTTAACGCG $-3^{\prime}$ (antisense). While the unmethylated primers were 5 '-TGAAGTTGTTGGGTTTGTAGTAAATTTT C-3' (sense), 5'-ATAAAAACATTCATAAACCACTT AACACA $-3^{\prime}$. The reaction mixture contained $2.0 \mu \mathrm{L}$ DNA, $0.5 \mu \mathrm{L}$ of each primer, $12.5 \mu \mathrm{L} 2 \times \mathrm{PCR}$ TaqMix, $9.5 \mu \mathrm{L}$ $\mathrm{ddH} 2 \mathrm{O}$, the complete MSP conditions were as follows: $94^{\circ} \mathrm{C}$ for 5 minutes, followed by 40 cycles of $94^{\circ} \mathrm{C}$ for 30 seconds, $56^{\circ} \mathrm{C}$ for 30 seconds, and $72^{\circ} \mathrm{C}$ for 2 minutes, with a final extension at $72^{\circ} \mathrm{C}$ for 10 minutes. The analysis was repeated on 3 different days. Finally, the PCR products were subjected to $2 \%$ agarose gel electrophoresis at $120 \mathrm{~V}$ for 40 minutes.

\section{Cell Proliferation Assay}

For the MTT assay, BGC-823 cells were seeded and transfected in a 96-well plate, with three wells in each group. At $0.5,1,2$, and 4 days, OD at $490 \mathrm{~nm}$ was selected to assess the absorbance of each well using an enzyme-linked immunometric meter. Experiments were repeated at least three times.

\section{Scratch-Wound Migration Assay}

A pipette was used to draw a horizontal line at the back of the six-well plate after the cells spread over the plate. Then PBS was used to wash the plate, and $0 \mu \mathrm{mol} / \mathrm{L}, 1 \mu \mathrm{mol} / \mathrm{L}$, $10 \mu \mathrm{mol} / \mathrm{L} 5$-Aza-CdR was added into the culture medium. Finally, an optical microscope was used to observe migration at 0 and 24 hours.

\section{Transwell Invasion Ability}

A total of $5 \times 10^{4}$ cells $/ \mathrm{mL}$ cells were plated in the upper chamber containing $200 \mu \mathrm{L}$ serum-free media, while the bottom chamber contained 600 medium supplemented with $10 \%$ FBS. After 48 hours, the migrated cells were fixed, stained, dried, and measured.

\section{5-Aza-CdR Inhibited Transplanted}

\section{Tumors in a Nude Mice Model}

A $0.2 \mathrm{~mL} 1 \times 107$ cells $/ \mathrm{mL}$ cell suspension of BGC-823 cells was injected into the back of nude mice. When the volume had grown into $10 \mathrm{~mm}^{3}, 40$ nude mice were randomly divided into two groups with 20 per group. 2mL PBS, 5-Aza-CdR (10 mol I山mol) was injected into the abdominal cavity. Next, 10 nude mice in each group were selected for calculating volume every 24 hours, tumor volume was monitored and calculated according to the formula: $\mathrm{V}(\mathrm{mm} 3)=0.526 \times \mathrm{L}$ (length) $\times \mathrm{W} 2($ width $)$ by measuring tumor length and width every 24 hours. At the end of the 15th day, each mouse was euthanized (by cervical dislocation) and the tumor tissues were removed for weighing. Furthermore, the tumor tissues were used for Western blot and Immunohistochemical staining. Finally, the other 10 nude mice in each group were used to record the survival time.

\section{Effect of Different Drug Treatment on Transplanted Tumors in a Nude Mice Model}

A total of $0.2 \mathrm{~mL} 1 \times 107$ cells $/ \mathrm{mL}$ cell suspension of BGC823 cell was injected into the back of nude mice. When the 
long diameter of the tumors grew into $0.5 \mathrm{~cm}, 32$ nude mice were randomly divided into four groups, with eight per group. In the control group, PBS was injected into the abdominal cavity on the first and 4th day. In the gemcitabine group, $5 \mathrm{mg} / \mathrm{kg}$ gemcitabine was injected into the abdominal cavity on the first day and PBS was injected into the abdominal cavity on the 4 th day. In the cisplatin group, PBS was injected into the abdominal cavity on the first day and $6 \mathrm{mg} /$ $\mathrm{kg}$ cisplatin was injected into the abdominal cavity on the 4th day. In the cCisplatin+gemcitabine group, $5 \mathrm{mg} / \mathrm{kg}$ gemcitabine was injected into the abdominal cavity on the first day, and $6 \mathrm{mg} / \mathrm{kg}$ cisplatin was injected into the abdominal cavity on the 4 th day. Tumor volume was monitored and calculated according to the formula: $\mathrm{V}\left(\mathrm{mm}^{3}\right)=0.526 \times$ $\mathrm{L}$ (length) $\times \mathrm{W}^{2}$ (width) by measuring tumor length and width every 24 hours.

\section{Results}

\section{Sox2 Has a Significantly}

\section{Clinicopathological Significance}

Sox2 Expression Level in Different Differentiated

\section{Gastric and Surrounding Nontumor Tissues}

The relationship between Sox 2 expression and progression of GC was investigated in cancerous and the surrounding nontumor tissues from 60 surgical specimens, RT-PCR indicated that there was no significant difference between well-differentiated tissues and surrounding nontumor tissues. However, Sox 2 mRNA was significantly higher in well-differentiated tissues than moderately differentiated and poorly differentiated tissues (Table 1 and Figure 1A), Meantime, Western-blotting indicated Sox 2 protein was obviously higher in well-differentiated tissues than moderately differentiated and poorly differentiated tissues (Figure 1B). In addition, immunohistochemistry was performed to detect the expression level of Sox 2 protein in different differentiation degree, well-differentiated tissues

Table I Relative Sox2 mRNA Expression Level in Different Differentiated Gastric Tissues and Surrounding Nontumor Tissues

\begin{tabular}{|l|l|l|l|}
\hline Differentiation Degree & Sox2 mRNA & t & P-value \\
\hline Well-differentiated & $2.483 \pm 0.18$ & & \\
Moderately differentiated & $4.645 \pm 0.24$ & 12.48 & $0.0002^{*}$ \\
Poorly differentiated & $4.734 \pm 0.13$ & 17.56 & $<0.000 I^{*}$ \\
Normal & $2.47 I \pm 0.09$ & 0.1033 & 0.9227 \\
\hline
\end{tabular}

Note: $* P<0.05$ was statistically significant. had a significantly higher positive rate than moderately differentiated and poorly differentiated tissues, and the positive rate of well-differentiated tissues were similar to the surrounding nontumor tissues (Table 2 and Figure $1 \mathrm{C}-\mathrm{F})$.

\section{The Association of Sox2 Expression with Clinicopathological Parameters}

To further investigate the association between Sox 2 expression and clinicopathological parameters. 60 samples were divided into two groups according to Sox 2 staining intensity, including high Sox2 staining $(n=19)$ and low Sox 2 staining $(n=41)$. We found the Sox 2 expression had a strong association with depth of invasion (0.0011), lymph node metastasis (0.0013) and TNM stage (0.0002). However, Sox 2 expression had no significant correlation with age $(0.4311$ and gender $(0.8960)$ (Table 3).

\section{DNA Methyltransferase Inhibitor Can Inhibit the Growth, Migration and Invasion of BGC-823 Cell Lines 5-Aza-CdR Reversed Methylation Status to Influence Sox2 Expression}

Western-blotting indicated Sox 2 protein was obviously lower in BGC-823 than normal gastric mucosa epithelium cell line GES-1 (Figure 2A), and methyltransferase inhibitor 5-AzaCdR could promote Sox 2 expression in a dose-dependent manner, Sox 2 expression level was higher in the $10 \mu \mathrm{mol} / \mathrm{L}$ group $(0.83 \pm 0.14)$ than in the $1 \mu \mathrm{mol} / \mathrm{L}(0.73 \pm 0.13)$ and 0 $\mu \mathrm{mol} / \mathrm{L}$ groups $(0.65 \pm 0.19)$ (Figure $2 \mathrm{~B})$. The MSP revealed that Sox2 gene promotor was in the status of methylation in BGC-823 (Figure 2C), and 5-Aza-CdR reversed status from methylation to nonmethylation status (Figure 2D).

\section{5-Aza-CdR Inhibited the Proliferation of BGC-823 cell Lines}

To investigate the effect of 5-Aza-CdR on cell proliferation, MTT assay was performed to assess the cell proliferation rate. In a fixed concentration, the cell proliferation inhibition rate increased with the prolonged time of administration of 5-Aza-CdR. Also, in a fixed time point, cell proliferation inhibition rate increased with increased concentration (Table 4 and Figure 3A).

\section{5-Aza-CdR Inhibited Migration Ability of BGC-823 Cell Lines \\ The migration distance of the $0 \mu \mathrm{mol} / \mathrm{L}$ group, the $1 \mu \mathrm{mol} / \mathrm{L}$ group and the $10 \mu \mathrm{mol} / \mathrm{L}$ group were $0.268 \pm 0.0190 \mathrm{~mm}$,}




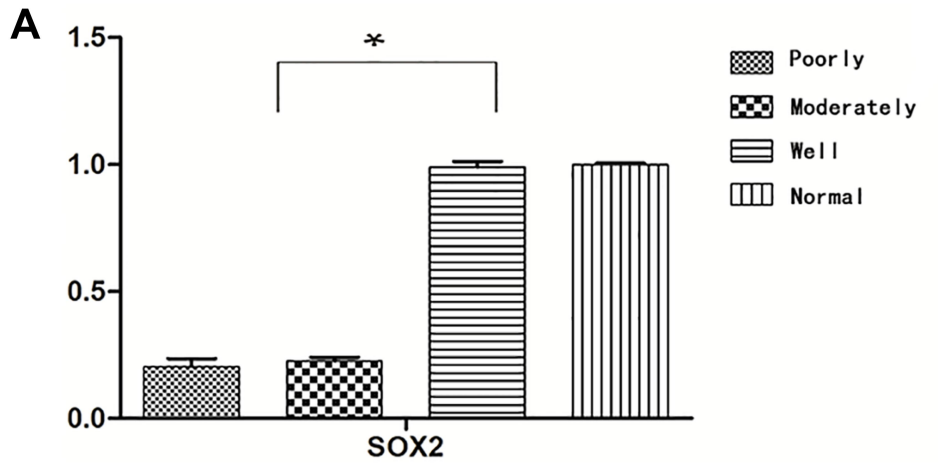

B
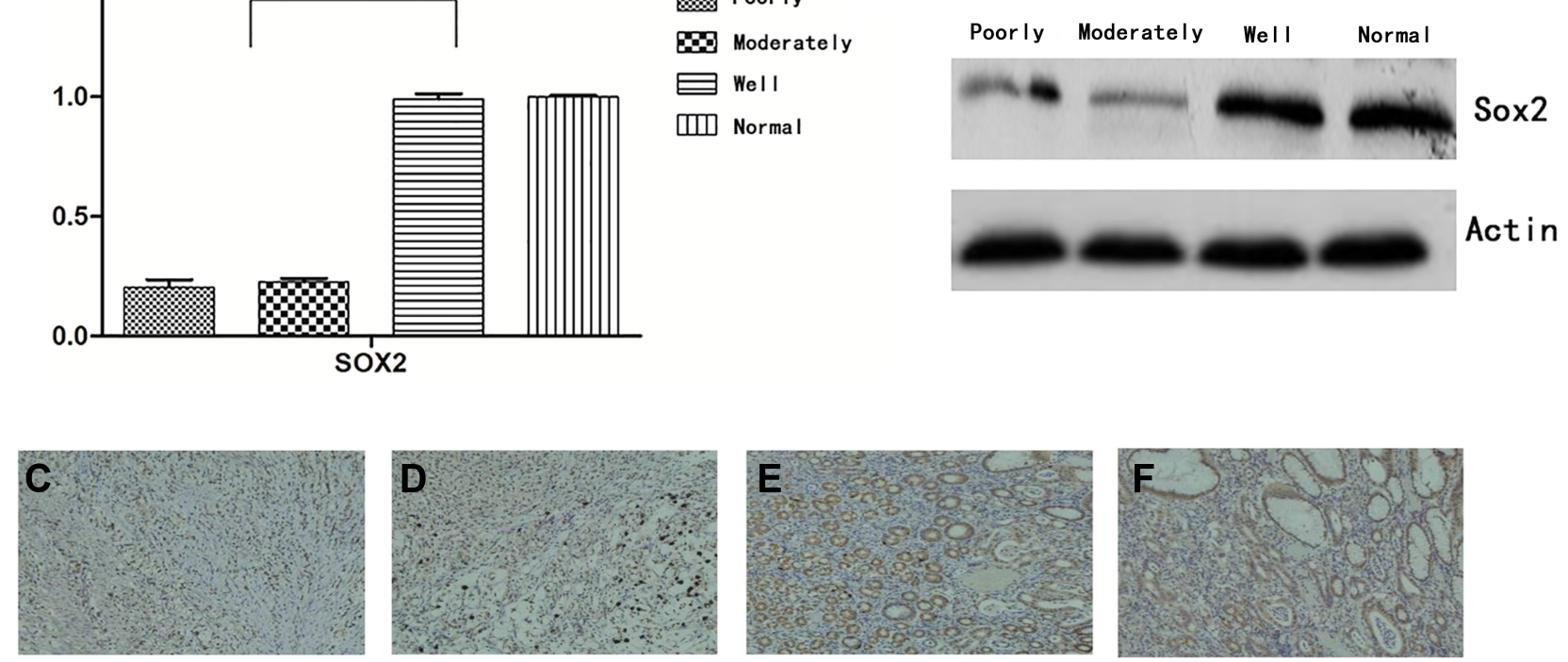

Figure I Expression of Sox2 in different degrees. (A) Sox2 mRNA using RT-PCR, (B) Sox2 protein using Western blot, (C-F) Sox2 protein using immunohistochemistry, (C) well-differentiated, (D) moderately differentiated, $(\mathbf{E})$ poorly differentiated, $(\mathbf{F})$ normal. $* P<0.05$, Compared with moderately differentiated and poorly differentiated tissues, Sox2 mRNA was significantly higher in well-differentiated tissues.

$0.020 \pm 0.008 \mathrm{~mm}$, and $0.010 \pm 0.001 \mathrm{~mm}$, respectively. The result revealed that the migration distance of $1 \mu \mathrm{mol} /$ $\mathrm{L}$ and $10 \mu \mathrm{mol} / \mathrm{L}$ group was significantly shorter compared with the $0 \mu \mathrm{mol} / \mathrm{L}$ group. Scratch-wound migration assay indicated 5-Aza-CdR could inhibit migration ability (Figure 3B).

\section{5-Aza-CdR Inhibited Invasion Ability of BGC-823 Cell Lines}

The number of BGC-823 invading and passing through the basement membrane was $188.60 \pm 10.90,75.20 \pm 6.18$ and $85.4 \pm 8.47$, respectively. Compared with the $0 \mu \mathrm{mol} / \mathrm{L}$ group, BGC-823 invading and passing through the basement membrane were significantly decreased in the 1 and $10 \mu \mathrm{mol} / \mathrm{L}$ groups. Transwell invasion assay indicated

Table 2 Sox2 Protein Expression Level in Different Differentiated Gastric Tissues and Surrounding Nontumor Tissues

\begin{tabular}{|l|l|l|l|l|l|}
\hline Differentiation Degree & \multirow{2}{*}{ Case } & \multicolumn{3}{|l|}{ Sox2 } \\
\cline { 3 - 6 } & & $\mathbf{( - )}$ & $\mathbf{( + )}$ & $\mathbf{( + + )}$ & $(+++)$ \\
\hline Well-differentiated & 19 & 13 & 6 & 2 & 0 \\
Moderately differentiated & 20 & 7 & 6 & 5 & 2 \\
Poorly differentiated & 21 & 1 & 8 & 6 & 4 \\
Normal & 20 & 4 & 1 & 5 & 10 \\
\hline
\end{tabular}

that 5-Aza-CdR could inhibit invasion ability (Figure 3C).

\section{5-Aza-CdR Inhibited Transplanted Tumor in Nude Mice Model}

The transplanted tumors in nude mice grew to about $125 \mathrm{~mm}^{3}$. Treatment was implied in the control and 5-Aza-CdR groups, though the 5-Aza-CdR group showed a slower increase in tumor volume compared with the control group. The final weight of transplanted tumor was $694.7 \pm 36.1 \mathrm{mg}$ in the control group and $325.2 \pm 32.2 \mathrm{mg}$ in the 5-Aza-CdR group, respectively. The tumor inhibition rate of 5 -Aza-CdR was $53.2 \%$, which indicated 5-Aza-CdR could inhibit tumor in vivo (Table 5 and Figure 4A).

\section{Western-Blotting Detecting Sox2 Protein from Transplanted Tumor}

Tumor tissue was taken out from nude mice after treatment. The protein expression level of Sox 2 was higher in the 5-Aza-CdR $(0.96 \pm 0.25)$ than in the control group $(0.73$ $\pm 0.15)(\mathrm{t}=16.052, P<0.0001)($ Figure 4B).

Immunohistochemistry Detecting Sox2 Protein from Transplanted Tumor

Tumor tissues were taken out from nude mice for immunohistochemistry, and protein expression level of 
Table 3 Correlation of Sox2 Expression with Clinicopathological Characteristics

\begin{tabular}{|c|c|c|c|c|c|}
\hline \multicolumn{2}{|l|}{ Characteristics } & \multicolumn{4}{|c|}{ Sox2 } \\
\hline & & \multirow{2}{*}{$\begin{array}{l}\text { All } \\
26 \\
34\end{array}$} & \multirow{2}{*}{$\begin{array}{l}\text { Poorly Differentiated } \\
8 \\
\text { II }\end{array}$} & \multirow{2}{*}{$\frac{\mathbf{x}^{2}}{0.01708}$} & \multirow{2}{*}{$\begin{array}{l}P \text {-value } \\
0.896\end{array}$} \\
\hline Gender & $\begin{array}{l}\text { Male } \\
\text { Female }\end{array}$ & & & & \\
\hline Age (years) & $\begin{array}{l}<60 \\
\geq 60\end{array}$ & $\begin{array}{l}18 \\
42\end{array}$ & $\begin{array}{l}7 \\
12\end{array}$ & 0.6198 & 0.4311 \\
\hline Depth of invasion & $\begin{array}{l}\text { TI-T2 } \\
\text { T3-T4 }\end{array}$ & $\begin{array}{l}23 \\
37\end{array}$ & $\begin{array}{l}13 \\
6\end{array}$ & 10.65 & $0.0011 *$ \\
\hline Lymph node metastasis & $\begin{array}{l}\text { Negative } \\
\text { Positive }\end{array}$ & $\begin{array}{l}18 \\
42\end{array}$ & $\begin{array}{l}11 \\
8\end{array}$ & 10.3 & $0.0013^{*}$ \\
\hline TNM stage & $\begin{array}{l}\text { I-II } \\
\text { III-IV }\end{array}$ & $\begin{array}{l}21 \\
39\end{array}$ & $\begin{array}{l}13 \\
6\end{array}$ & 13.65 & $0.0002 *$ \\
\hline
\end{tabular}

Note: $* \mathrm{P}<0.05$ was statistically significant.

Sox2 was detected by immunohistochemistry. The 5-Aza-CdR group demonstrated strong Sox2 staining while the control group showed weak Sox2 staining. The expression score in the 5-Aza-CdR group was higher than in the control group (Figure 4C).

\section{Gemcitabine and Cisplatin Were} Synergistic to Inhibit Tumor Growth Through Sox2 Methylation in BGC-823

\section{Cell Lines}

\section{Effect of Different Treatments on Sox2 Methylation} in BGC-823 Cell Lines

After treating with different drug treatments, BGC-823 was taken out for MSP to assess Sox2 promoter. As shown in Figure 5, it revealed that the methylated band of Sox 2 was very strong while the unmethylated band was very weak in the control group. In the $5 \mathrm{mg} / \mathrm{kg}$ gemcitabine group, the unmethylated band was obvious, however, the methylated band was relatively weaker than the control group. After treating with different concentrations of cisplatin $(1 \mu \mathrm{M}, 10 \mu \mathrm{M}$ and $100 \mathrm{Mm})$, the unmethylated band was gradually more obvious as the concentration increased. After treating with gemcitabine and different concentrations of cisplatin $(1 \mu \mathrm{M}, 10 \mu \mathrm{M}$ and $100 \mu \mathrm{M})$, the unmethylated band was gradually more obvious and the methylated band was gradually weaker as the centration of cisplatin increased. The result indicated Sox 2 promoter was hypermethylated and $5 \mathrm{mg} / \mathrm{kg}$ gemcitabine could partly reverse the methylated status. With centration of cisplatin increased, the unmethylated band had an increasing trend. Gemcitabine and different concentrations of cisplatin $(1 \mu \mathrm{M}, 10 \mu \mathrm{M}$ and $100 \mu \mathrm{M})$ were synergistic to reverse the methylated status.

\section{Effect of Different Treatments on Sox2 mRNA Expression in BGC-823 Cell Lines}

After treating with different drug treatments, BGC-823 cell lines were taken out for RT-PCR to detect Sox2 mRNA expression. As shown in Figure 6A, compared with the control group, Sox 2 mRNA expression level markedly increased. After treating with different concentrations of cisplatin $(1 \mu \mathrm{M}, 10 \mu \mathrm{M}$ and $100 \mu \mathrm{M})$, Sox 2 mRNA expression level demonstrated a trend of a slow rise. THe combination of gemcitabine and different concentrations of cisplatin $(1 \mu \mathrm{M}, 10 \mu \mathrm{M}$ and $100 \mu \mathrm{M})$ could further increase SOX2 mRNA expression level.

\section{Effect of Different Treatments on Sox2 Protein in BGC-823 Cell Lines}

After treating with different drug treatments, Western blot was performed to detect Sox 2 protein. As shown in Figure $6 \mathrm{~B}$, Figure $6 \mathrm{C}$ and Table 6 , the expression of SOX2 protein was hardly detected in the control group. After treating with gemcitabine, Sox 2 protein level markedly increased. After treating with different concentrations of cisplatin $(1 \mu \mathrm{M}, 10 \mu \mathrm{M}$ and $100 \mu \mathrm{M})$, SOX2 protein demonstrated a trend of slow rise. Combination of 
A

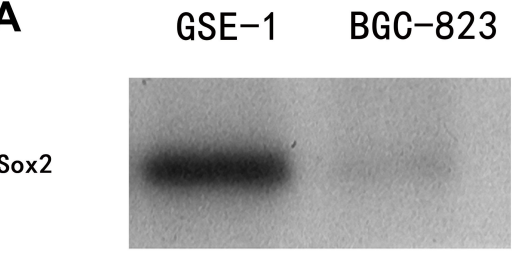

beta-actin

B

$0 \mu \mathrm{mol} / \mathrm{L} \quad 1 \mu \mathrm{mol} / \mathrm{L} 10 \mu \mathrm{mol} / \mathrm{L}$

Sox2



beta-act in


BGC-823

H20

C Marker

GES-1

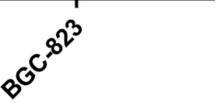

U

M

U

M

600

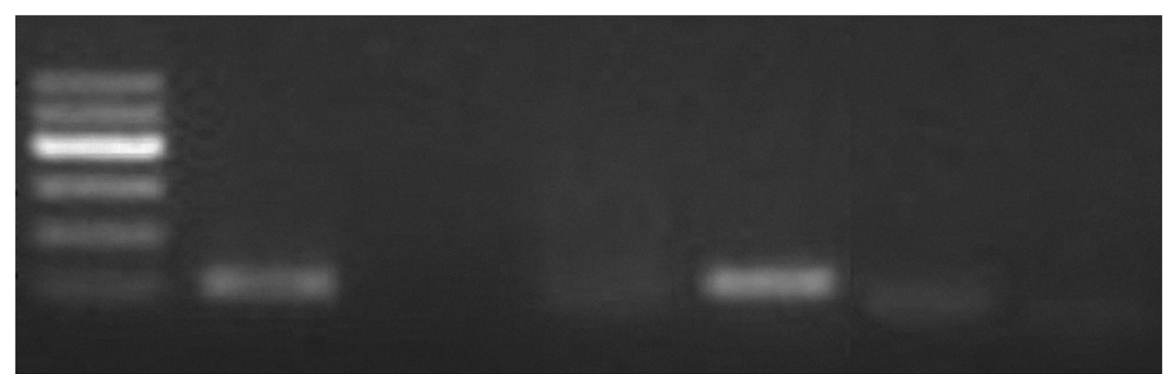

D

$$
\text { Marker }
$$

GES-1

BGC-823

H2O

U

M

U

M

U

M

600

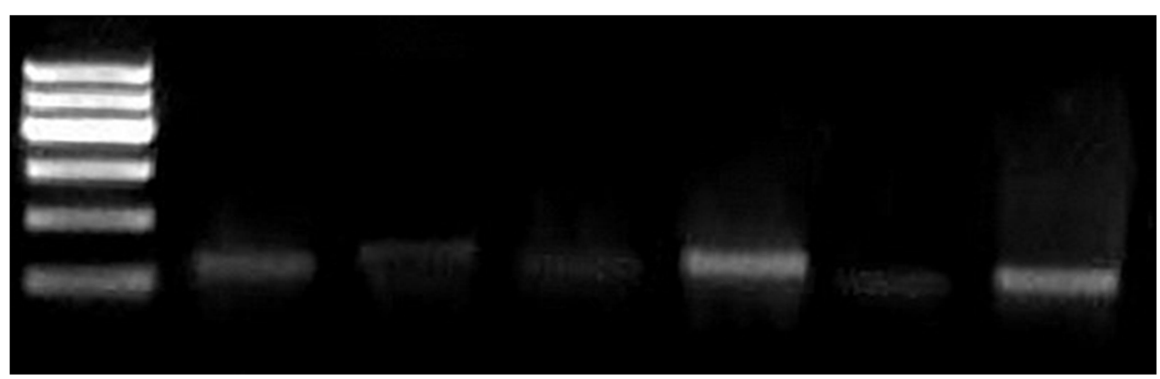

Figure 2 5-Aza-CdR could reverse methylation status to influence Sox2 expression. (A) Sox2 protein between GSE-I and BCG-823, (B) Sox2 protein using 5-Aza-CdR with different dose. (C) The MSP showed that Sox2 methylation status in BGC-823. (D) The MSP showed that Sox2 unmethylation status using 5-Aza-CdR in BGC-823. Marker: 600 bp DNA Ladder Marker.

Abbreviations: $U$, unmethylation; $M$, methylation. 
Table 4 The Effect of Different Concentrations on Proliferation Inhibition Rate of BGC-823 in Different Time Points

\begin{tabular}{|l|l|l|l|l|}
\hline \multirow{2}{*}{ Concentration ( $\mu \mathrm{mol} / \mathrm{L})$} & \multicolumn{4}{l|}{ Time (h) } \\
\cline { 2 - 6 } & 12 & $\mathbf{2 4}$ & $\mathbf{4 8}$ & $\mathbf{9 6}$ \\
\hline 0 & 0 & 0 & 0 & 0 \\
1 & $6.11 \pm 1.09$ & $11.59 \pm 1.15^{\mathrm{b}}$ & $17.52 \pm 1.22^{\mathrm{b}}$ & $19.35 \pm 0.61^{\mathrm{b}}$ \\
10 & $47.38 \pm 2.67^{\mathrm{a}}$ & $61.71 \pm 4.11^{\mathrm{a}, \mathrm{b}}$ & $68.35 \pm 3.61^{\mathrm{a}, \mathrm{b}}$ & $75.57 \pm 3.44^{\mathrm{a}, \mathrm{b}}$ \\
20 & $50.23 \pm 3.25^{\mathrm{a}}$ & $63.93 \pm 2.89^{\mathrm{a}, \mathrm{b}}$ & $73.03 \pm 4.05^{\mathrm{a}, \mathrm{b}}$ & $79.74 \pm 2.88^{\mathrm{a}, \mathrm{b}}$ \\
\hline
\end{tabular}

Notes: ${ }^{a} \mathrm{P}<0.05$, compared with the I $\mu \mathrm{mol} / \mathrm{L}$ group; ${ }^{\mathrm{b}} \mathrm{P}<0.05$, compared with the 12 -hour group.

gemcitabine and different concentrations of cisplatin (1 $\mu \mathrm{M}, 10 \mu \mathrm{M}$ and $100 \mu \mathrm{M}$ ) could further increase SOX2 protein expression level. Compared with the $5 \mu \mathrm{M}$ gemcitabine group, SOX2 protein was significantly higher in the $5 \mu \mathrm{M}$ gemcitabine $+1 \mu \mathrm{M}$ cisplatin group $(P<0.05), 5 \mu \mathrm{M}$ gemcitabine $+10 \mu \mathrm{M}$ cisplatin group $(P<0.01)$ and $5 \mu \mathrm{M}$ gemcitabine $+100 \mu \mathrm{M}$ cisplatin group $(P<0.01)$. Compared with the $5 \mu \mathrm{M}$ gemcitabine $+10 \mu \mathrm{M}$ cisplatin group, there was no significant difference in the $5 \mu \mathrm{M}$ gemcitabine +1 $\mu \mathrm{M}$ cisplatin group $(P>0.05)$ and in the $5 \mu \mathrm{M}$ gemcitabine $+100 \mu \mathrm{M}$ cisplatin group $(P>0.05)$.

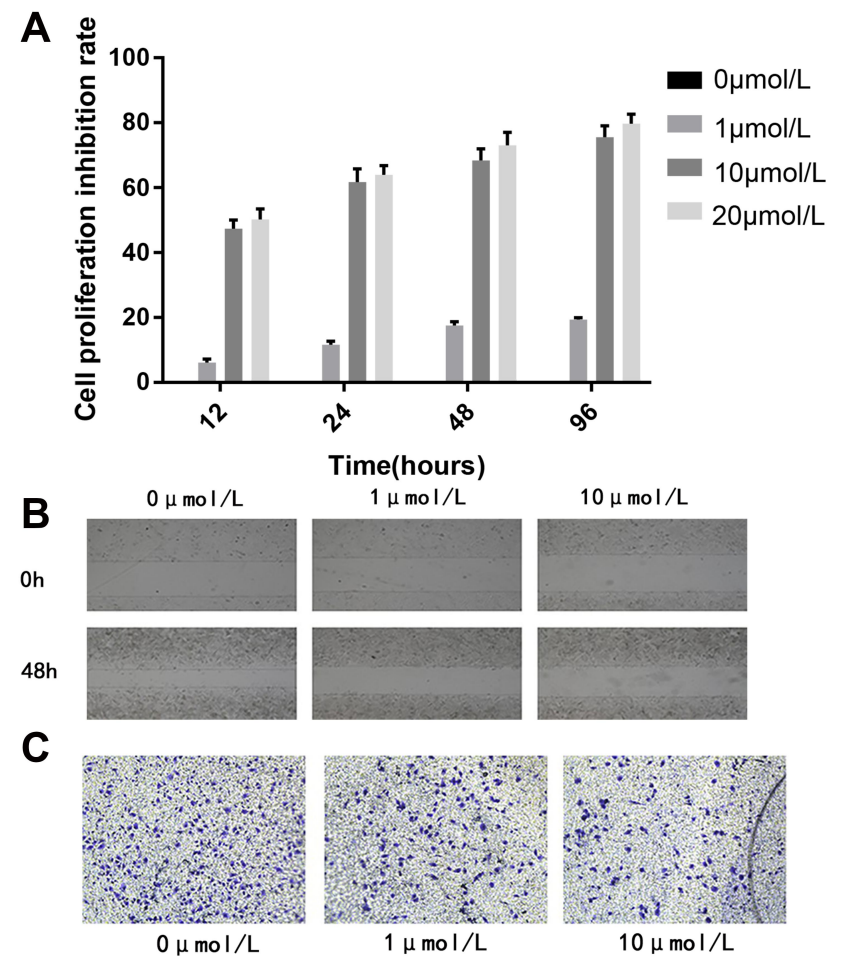

Figure 3 5-Aza-CdR could inhibit the proliferation, migration and invasion ability of BGC-823 cell lines.(A) Cell proliferation inhibition rate, (B) Cell migration image, (C) Cell invasion image.
Gemcitabine and Cisplatin are Synergistic to Inhibit Tumor Growth Through Sox2 Methylation in a Nude Mice Model Effect of Different Treatments on Transplanted Tumor Growth

During the first 2 weeks, tumors were observed, measured, and recorded every 2 days. Since the 6th day, there was a significant difference in tumor volume between the gemcitabine + cisplatin group and the other three groups. After the 10th day, there was a significant difference in tumor volume between the $5 \mathrm{mg} / \mathrm{kg}$ gemcitabine group and the control group. Since the 8 th day, the $6 \mathrm{mg} / \mathrm{kg}$ cisplatin group had a significant difference compared with the control group (Figure 7).

\section{Effect of Different Treatments on Sox2 Methylation in a Nude Mice Model}

Tumor tissues were taken out from nude mice for MSP to assess Sox 2 promoter. The result indicated that methylated band of Sox 2 was very strong in the control group, while the unmethylated band was very weak. In the $5 \mathrm{mg} /$ $\mathrm{kg}$ gemcitabine group, the unmethylated band was obvious, however, the methylated band was relatively weaker than in the control group. Meantime, in the $6 \mathrm{mg} / \mathrm{kg}$ cCisplatin group, the unmethylated band was weak and the methylated band was very obvious. Furthermore, in the $5 \mathrm{mg} / \mathrm{kg}$ gemcitabine $+6 \mathrm{mg} / \mathrm{kg}$ cisplatin group, the unmethylated band was very obvious, while the methylated band was weakened further. The result indicated that the Sox 2 promoter was hypermethylated in the control group, and $5 \mathrm{mg} / \mathrm{kg}$ gemcitabine could partly reverse the methylated status, while the impact of $6 \mathrm{mg} / \mathrm{kg}$ cisplatin on methylated status was limited. However, $5 \mathrm{mg} / \mathrm{kg}$ gemcitabine and $6 \mathrm{mg} / \mathrm{kg}$ cisplatin could be synergistic to reverse the methylated status (Figure 8). 
Table 5 Effect of 5-Aza-CdR on Transplanted Tumors in a Nude Mice Model

\begin{tabular}{|c|c|c|c|c|c|c|c|c|c|c|}
\hline \multirow[t]{2}{*}{ Group } & \multicolumn{6}{|c|}{ Tumor Volume $\left(\mathrm{mm}^{3}\right)$} & \multirow{2}{*}{$\begin{array}{l}\text { Tumor } \\
\text { Weight } \\
\text { (mg) }\end{array}$} & \multirow{2}{*}{$\begin{array}{l}\text { Inhibition } \\
\text { Rate (\%) }\end{array}$} & \multirow{2}{*}{$\begin{array}{l}\text { Survival } \\
\text { Days }\end{array}$} & \multirow{2}{*}{$\begin{array}{l}\text { Median } \\
\text { Survival } \\
\text { Days }\end{array}$} \\
\hline & 0 day & 3 days & 6 days & 9 days & 12 days & 15 days & & & & \\
\hline PBS & $126.4 \pm 6.3$ & $|88.4 \pm| 3.8$ & $253.7 \pm 29.8$ & $328.1 \pm 39.3$ & $4 \mid 5.3 \pm 47.1$ & $540.7 \pm 42.6$ & $694.7 \pm 36.1$ & 0.0 & $18.7 \pm 1.6$ & 18.5 \\
\hline 5-Aza-CdR & $128.6 \pm 4.6$ & $167.0 \pm 16.8^{\mathrm{a}}$ & $189.3 \pm 20.0^{a}$ & $214.9 \pm 25.2^{\mathrm{a}}$ & $244.5 \pm 29.7^{a}$ & $286.6 \pm 37.5^{\mathrm{a}}$ & $325.2 \pm 32.2^{\mathrm{a}}$ & 53.2 & $22.5 \pm 1.0^{\mathrm{a}}$ & 22.5 \\
\hline
\end{tabular}

Note: ${ }^{a} P<0.05$, compared with control group.

Abbreviation: PBS, phosphate buffer saline.

\section{Effect of Different Treatments on Sox2 mRNA Expression in a Nude Mice Model}

Transplanted tumors were taken out for qRT-PCR to detect

Sox 2 mRNA. Compared with the control group, Sox 2

A PBS control group

\section{5-Aza-CdR group}
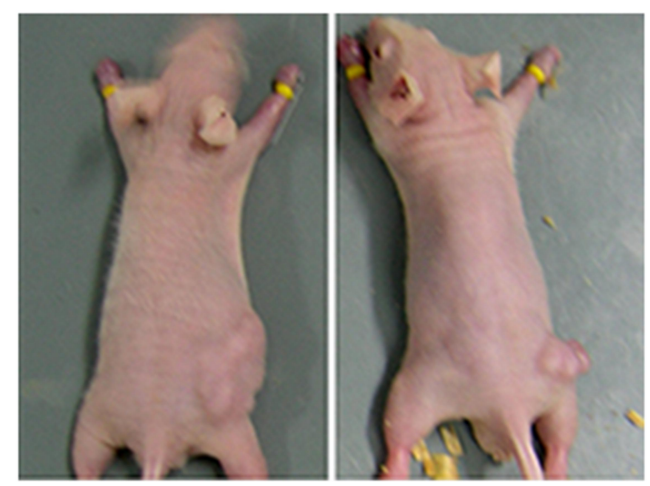

B

Sox 2

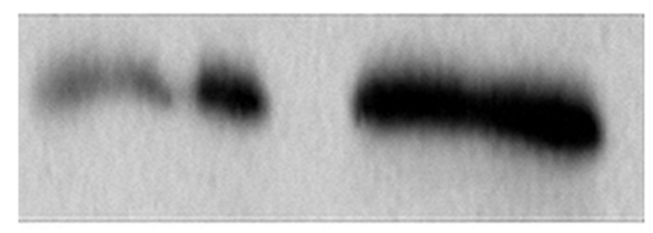

Beta-actin

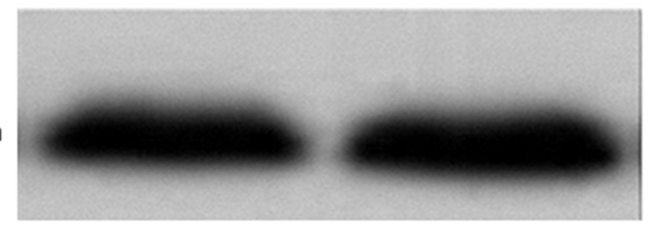

\section{C}

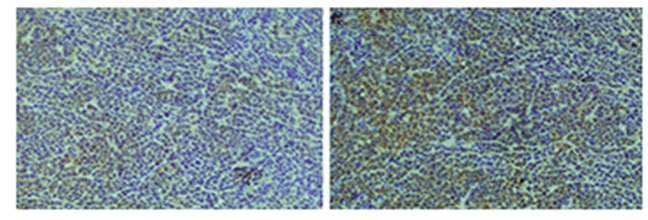

Figure 4 5-Aza-CdR inhibited transplanted tumor in a nude mice model. (A) Tumor photograph that nude mice wore in control and 5-Aza-CdR group, (B) Western-blotting detecting Sox2 protein from transplanted tumor, (C) Immunohistochemistry detecting Sox2 protein from transplanted tumor.
mRNA was higher in the $6 \mathrm{mg} / \mathrm{kg}$ cisplatin group, with no significance $(P>0.05)$, while Sox 2 mRNA in the $5 \mathrm{mg} /$ $\mathrm{kg}$ gemcitabine group was significantly higher $(P<0.01)$. THe combination of $5 \mathrm{mg} / \mathrm{kg}$ gemcitabine $+6 \mathrm{mg} / \mathrm{kg}$ cisplatin treatment was marginally higher than the control group $(P<0.01)$, the $6 \mathrm{mg} / \mathrm{kg}$ cisplatin group $(P<0.01)$ and the $5 \mathrm{mg} / \mathrm{kg}$ gemcitabine group $(P<0.01)$. The result demonstrated that $6 \mathrm{mg} / \mathrm{kg}$ cisplatin and $5 \mathrm{mg} / \mathrm{kg}$ gemcitabine could promote Sox 2 expression, and the combination of $5 \mathrm{mg} / \mathrm{kg}$ gemcitabine $+6 \mathrm{mg} / \mathrm{kg}$ cisplatin treatment could be synergistic to promote Sox 2 mRNA expression (Figure 9A and Table 7).

\section{Effect of Different Treatments on Sox2 Protein Expression in a Nude Mice Model}

Transplanted tumors were taken out for Western blot to detect Sox 2 protein. Compared with the control group, there was no significance in the $6 \mathrm{mg} / \mathrm{kg}$ cisplatin group, though there was a significant difference between the control group and the $5 \mathrm{mg} / \mathrm{kg}$ gemcitabine group. Compared with the single control group, $6 \mathrm{mg} / \mathrm{kg}$ cisplatin group $(P<0.01)$ and the $5 \mathrm{mg} / \mathrm{kg}$ gemcitabine group, the combination of $5 \mathrm{mg} / \mathrm{kg}$ gemcitabine + $6 \mathrm{mg} / \mathrm{kg}$ cisplatin treatment revealed a striking difference (Figure 9B, Figure 9C and Table 8).

\section{Discussion}

Reversing gene silencing through DNA methylation is an effective anti-tumor therapy, and methylation inhibitors could reactivate various cancer suppressor genes. ${ }^{25,26}$ Decitabine is the representative methylation inhibitor. However, few studies have focused on the effect of cisplatin on DNA methylation. Meantime, it is not clear whether cisplatin and decitabine are synergistic to promote DNA demethylation. In the present study, we intended to investigate the effect of the combination of decitabine and cisplatin on the DNA methylation status of Sox 2 gene in GC. 




Figure 5 Effect of different treatments on Sox2 methylation in BGC-823 cell lines. Marker: 600 bp DNA Ladder Marker. Abbreviations: $U$, unmethylation; $M$, methylation.

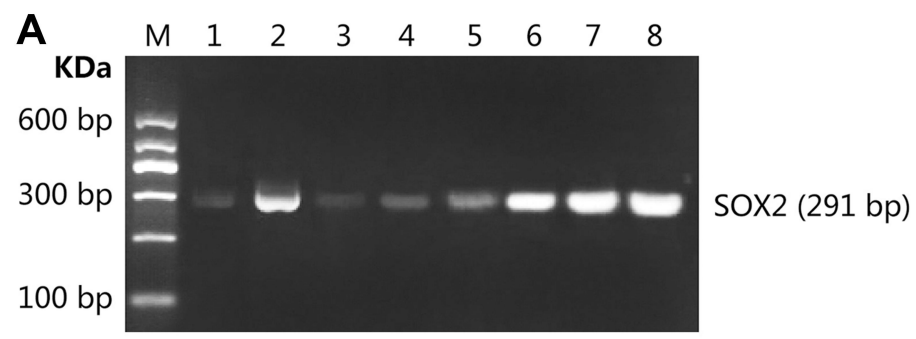

B
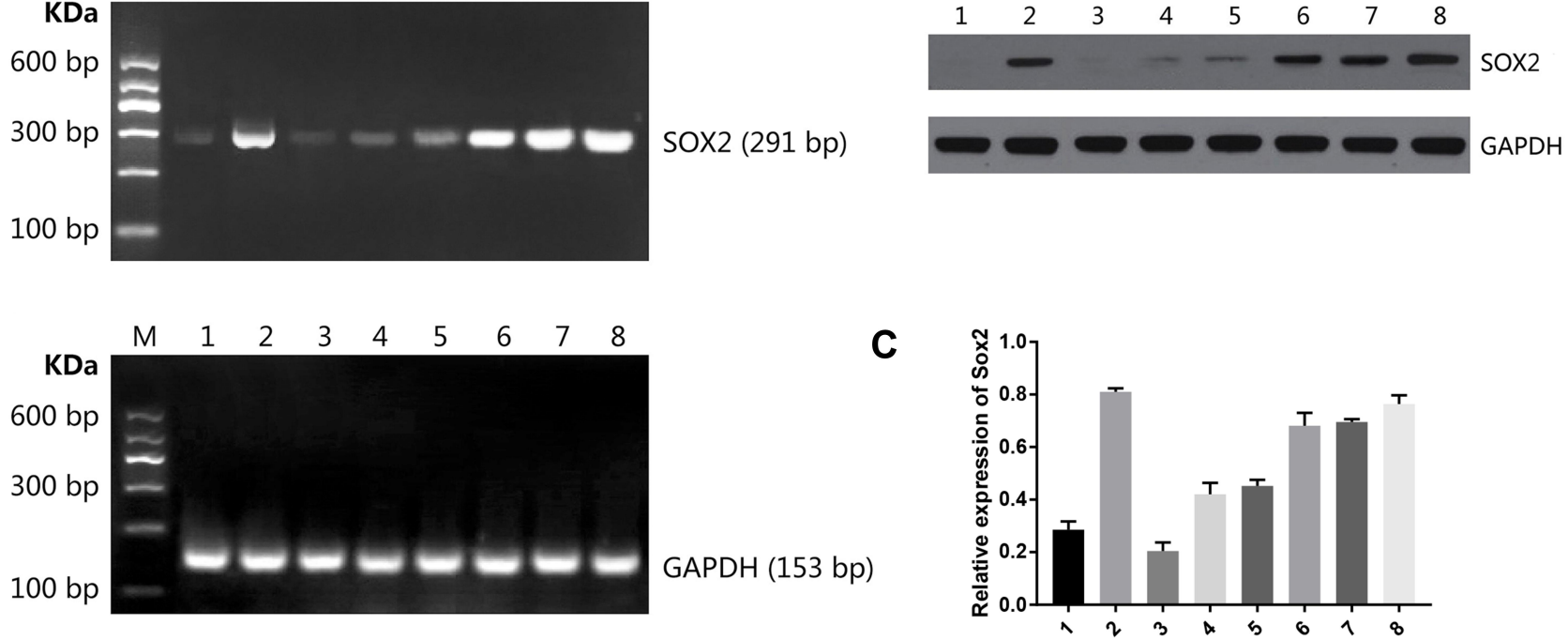

Figure 6 Effect of different treatments on Sox2 expression in BGC-823 cell lines. (A) Sox2 mRNA, (B) Sox2 protein image, (C) Sox2 protein histogram. M DNA Marker; I: control group; 2: $5 \mu \mathrm{M}$ decitabine; 3: I $\mu \mathrm{M}$ cisplatin; 4: $10 \mu \mathrm{M}$ cisplatin; 5: $100 \mu \mathrm{M}$ cisplatin; 6: $5 \mu \mathrm{M}$ decitabine +I $\mu \mathrm{M}$ cisplatin; 7: $5 \mu \mathrm{M}$ decitabine + I0 $\mu \mathrm{M}$ cisplatin; 8: $5 \mu \mathrm{M}$ decitabine $+100 \mu \mathrm{M}$ cisplatin.

Sox2 belongs to a member of the Sox (SRY-related HMG-box) gene family, which encodes transcription factors associated with sex determining region $\mathrm{Y}$ gene (SRY). Sox2 plays a regulatory role in the development of early embryos and maintaining progenitor cell self-renewal, and plays vital roles in differentiation of gastric mucosa. The aberrant expression is involved in gastritis, intestinal metaplasia and GC. ${ }^{6,27-31}$ Recently, It is reported that Sox 2 is correlated with tumor initiation and progression. Meantime, abnormal overexpression is associated with various cancers, such as lung cancer $^{32}$ and prostatic cancer. $^{33}$

We reviewed previous studies and found the discordance between Sox 2 expression and clinicopathological features. Some research revealed that Sox2 is upregulated in gastric cancer cells ${ }^{9,11}$ and gastric cancer stem cells, ${ }^{10}$ which indicated Sox 2 might be the oncogene to promote the occurrence and progress. Matsuoka et $\mathrm{al}^{11}$ revealed Sox 2 overexpression is associated with strong invasiveness, poor prognosis and high TNM grade. 
Table 6 The Effect of Different Treatments on Sox2 mRNA Expression Level in BGC-823

\begin{tabular}{|l|l|}
\hline Group & $\begin{array}{l}\text { Sox2 mRNA/GAPDH } \\
\text { mRNA }\end{array}$ \\
\hline Control group & $0.16 \pm 0.07$ \\
$5 \mu \mathrm{M}$ emcitabine & $1.07 \pm 0.09^{\ddagger}$ \\
$1 \mu \mathrm{M}$ cisplatin & $0.11 \pm 0.04$ \\
$10 \mu \mathrm{M}$ isplatin & $0.25 \pm 0.06$ \\
$100 \mu \mathrm{M}$ cisplatin & $0.44 \pm 0.04$ \\
$5 \mu \mathrm{M}$ gemcitabine+1 $\mu \mathrm{M}$ cisplatin & $1.31 \pm 0.10^{\#}$ \\
$5 \mu \mathrm{M}$ gemcitabine+10 $\mu \mathrm{M}$ cisplatin & $1.73 \pm 0.15^{*}$, \\
$5 \mu \mathrm{M}$ gemcitabine+100 $\mu \mathrm{M}$ cisplatin & $2.19 \pm 0.16^{* *,}$, \\
\hline
\end{tabular}

Note: ${ }^{\ddagger} p<0.01$, compared with control group; ${ }^{\#} p>0.05$, compared with $5 \mu \mathrm{M}$ gemcitabine; $* P<0.05$, compared with $5 \mu \mathrm{M}$ gemcitabine; $* * P<0.01$, compared with $5 \mu \mathrm{M}$ gemcitabine; ${ }^{\Delta} \mathrm{P}<0.0 \mathrm{I}$, compared with $5 \mu \mathrm{M}$ gemcitabine+I $\mu \mathrm{M}$ cisplatin; ${ }^{\Delta} P<0.01$, compared with $5 \mu M$ gemcitabine $+10 \mu M$ cisplatin.

Abbreviation: GAPDH, glyceraldehyde-3-phosphate dehydrogenase.

However, more studies indicated Sox2 functions as an anti-tumor role. Otsubo et $\mathrm{al}^{13}$ and Zhang et $\mathrm{al}^{16}$ revealed that patients with positive Sox 2 are correlated with favorable prognosis, Wang et $\mathrm{al}^{17}$ reported that SOX2 protein expression could be used as an independent prognostic indicator of GC. In consistency with our result, we found Sox2 protein level was significantly higher in welldifferentiated tissues than in moderately differentiated and poorly differentiated tissues, and no significant difference has been observed between well-differentiated and surrounding nontumor tissues. Furthermore, Sox2

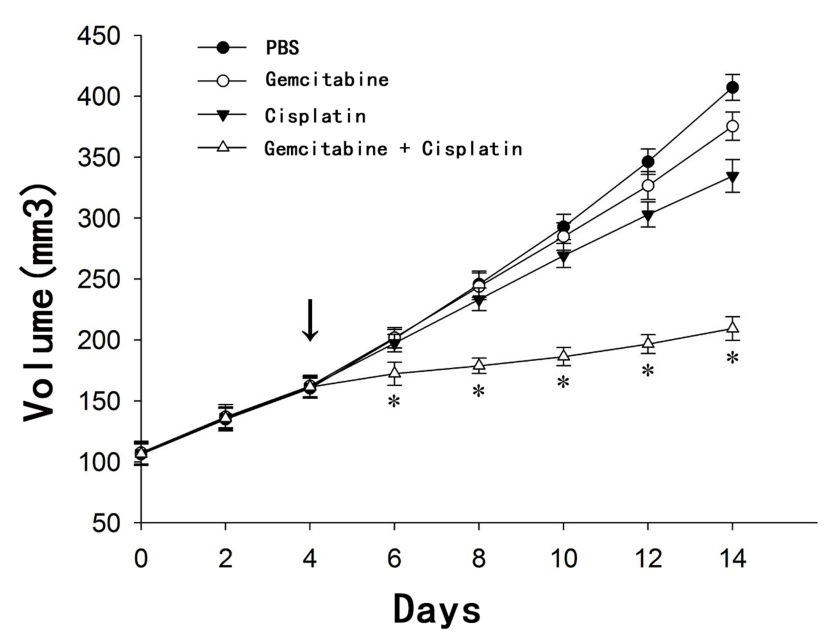

Figure 7 Effect of different treatments on transplanted tumor growth in a nude mice model. $* P<0.01$, there wasa significant difference in tumor volume between the gemcitabine + cisplatin group and the other three groups since the 6th day; The arrow indicator, at the 4th day, PBS, PBS, $6 \mathrm{mg} / \mathrm{kg}$ cisplatin and $6 \mathrm{mg} / \mathrm{kg}$ cisplatin was injected into the abdominal cavity of the control group, the gemcitabine group, the cisplatin group and the cisplatin + gemcitabine group, respectively.

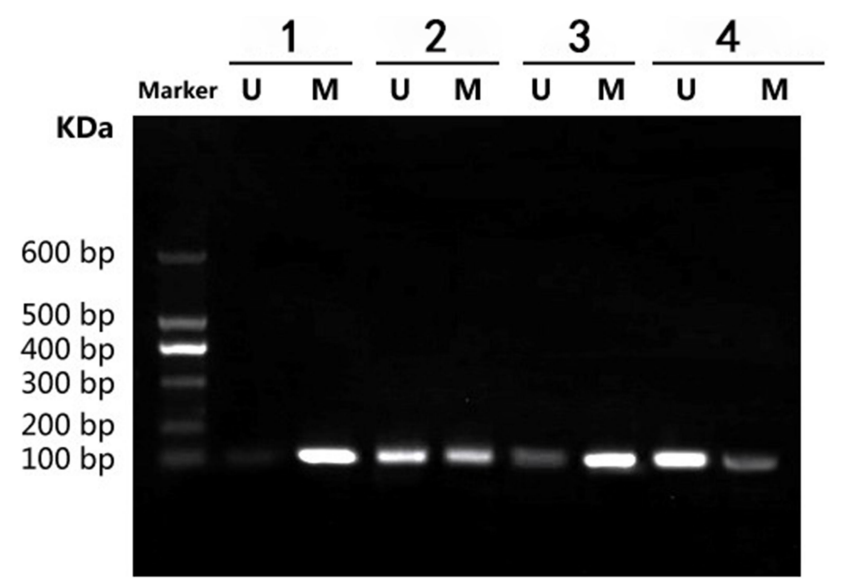

Figure 8 Effect of different treatments on Sox 2 methylation in a nude mice model. l) control group; 2) $5 \mathrm{mg} / \mathrm{kg}$ decitabine; 3) $6 \mathrm{mg} / \mathrm{kg}$ cisplatin; 4) $5 \mathrm{mg} / \mathrm{kg}$ decitabine + $6 \mathrm{mg} / \mathrm{kg}$ cisplatin.

expression had a strong association with invasion (0.0011), lymph node metastasis (0.0013) and TNM stage (0.0002). Thus it is believed that Sox2 is a cancer suppressor gene in GC. Next, compared with normal gastric mucosa epithelium cell line GES-1, the Sox2 expression level was lower in gastric cancer cell line BGC-82, 5-Aza-CdR could promote Sox 2 expression in a dosedependent manner, which indicated hypermethylation inhibits Sox 2 expression in gastric cancer cells. Furthermore, we found several oncology characteristics of BGC-82 remarkably decreased by using 5 -Aza-CdR, such as proliferation, migration and invasiveness. Finally, it have been validated in BGC-82 and nude mice model. Therefore, DNMT inhibitor could reactivate Sox 2 to inhibit progression of gastric cancer cells in vivo and vitro.

As the representative of a demethylated drug, decitabine has been widely applied to hematological malignant tumors in clinical trials. However, relevant research associated with solid tumor is limited, especially gastric cancer. Tian et $\mathrm{al}^{34}$ have revealed decitabine could inhibit gastric tumor xenografts in a nude mice model because of NES1 promoter methylation. Liang et $\mathrm{al}^{35}$ reported that decitabine could inhibit HepG2 cell xenografts in a nude mice model by reversing T-cadherin expression via demethylating NES1 promoter. Plumb et $\mathrm{al}^{36}$ indicated that decitabine could increase the sensitivity to cisplatin, carboplatin, temozolomide and doxorubicin. Compared with monotherapy, the combination of doxorubicin and histone acetylation inhibitor belinostat significantly reversed MLH1 and MAGE-A1 expression to increase drug 


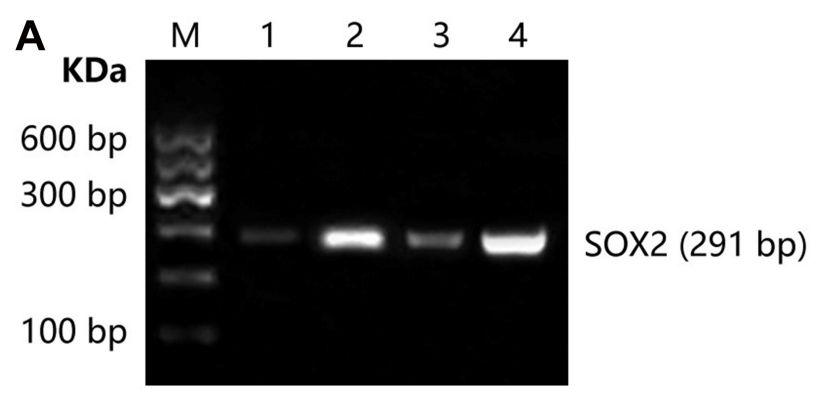

B
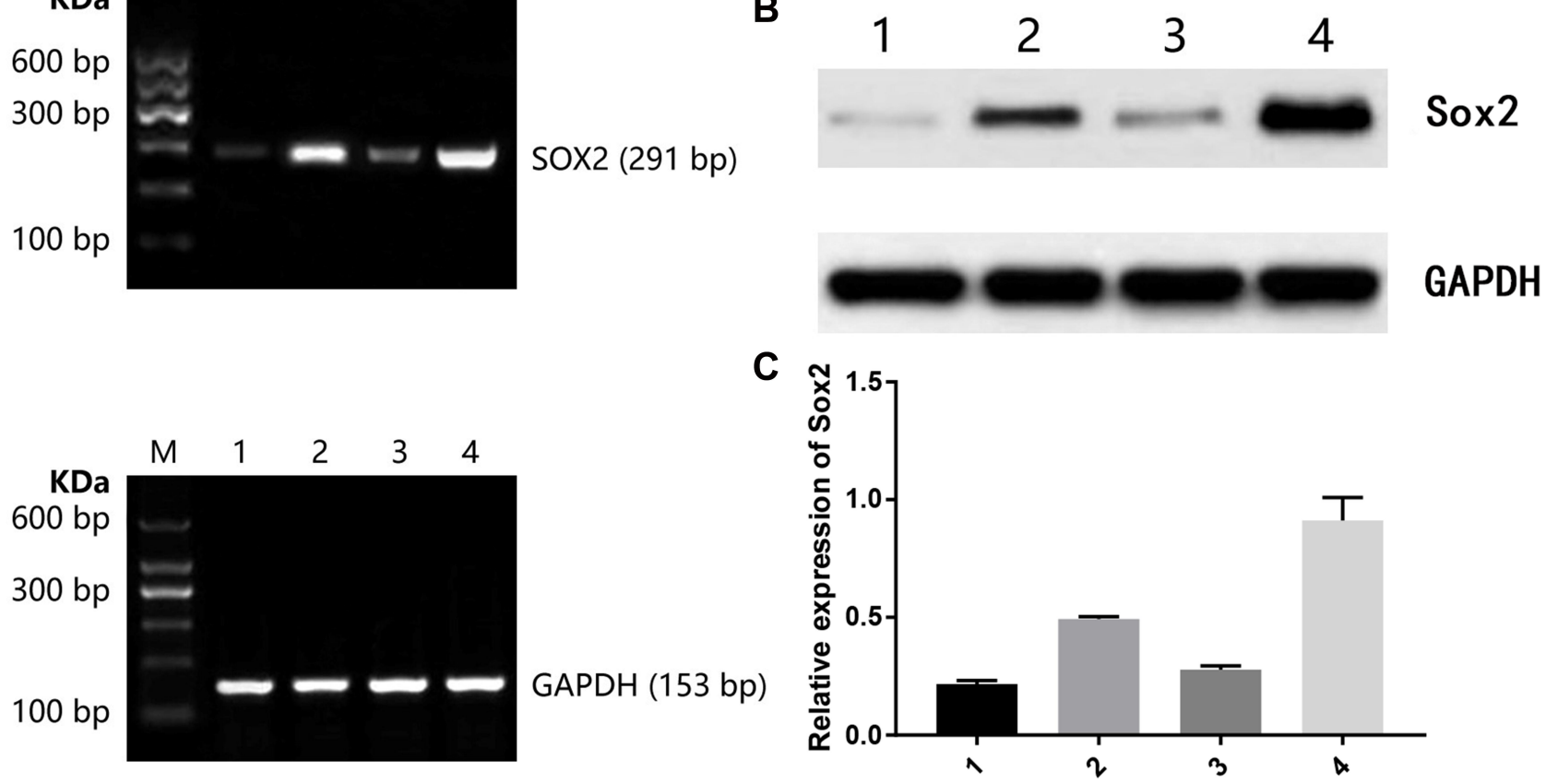

Figure 9 Effect of different treatments on Sox2 expression in a nude mice model. (A) Sox2 mRNA, (B) Sox2 protein image, (C) Sox2 protein histogram. I) control group; 2) $5 \mathrm{mg} / \mathrm{kg}$ decitabine; 3) $6 \mathrm{mg} / \mathrm{kg}$ cisplatin; 4) $5 \mathrm{mg} / \mathrm{kg}$ decitabine $+6 \mathrm{mg} / \mathrm{kg}$ cisplatin.

sensitivity of the cisplatin-resistant human ovarian cancer cells A2780/CP70 xenografts in a nude mice model.

BGC-823 cell lines whose Sox2 methylation status is easily influence by decitabine, were applied to investigate whether decitabine and cisplatin are synergistic to influence methylated status and expression level of Sox2. Our study revealed that decitabine could promote Sox2 demethylation, and increase mRNA and protein expression level of Sox2. In addition, cisplatin could also reduce methylation level and the combination of cisplatin and decitabine has a more obvious effect. It indicated that cisplatin could reverse methylation status in gastric cancer cell lines, which has not been reported in previous studies.

Table 7 The Effect of Different Treatments on Sox2 mRNA Expression Level in a Nude Mice Model

\begin{tabular}{|l|l|l|}
\hline Group & $\begin{array}{l}\text { Sox2 mRNA/ } \\
\text { GAPDH mRNA }\end{array}$ & P-value \\
\hline Control group & $0.14 \pm 0.06$ & \\
$5 \mathrm{mg} / \mathrm{kg}$ emcitabine & $1.09 \pm 0.17$ & $<0.01$ \\
$6 \mathrm{mg} / \mathrm{kg}$ isplatin & $0.33 \pm 0.08$ & $>0.05$ \\
$5 \mathrm{mg} / \mathrm{kg}$ emcitabine $+6 \mathrm{mg} / \mathrm{kg}$ & $1.31 \pm 0.15$ & $<0.01$ \\
emcitabine & & \\
\hline
\end{tabular}

Abbreviation: GAPDH, glyceraldehyde-3-phosphate dehydrogenase.
In summary, decitabine, cisplatin and combined therapy could promote Sox 2 demethylation and increase mRNA and protein expression, while decitabine and cisplatin play a synergistic effect.

In order to investigate whether dDecitabine and cisplatin are synergistic to inhibit GC, we constructed a nude mouse transplantation model to assess the synergistic effect of decitabine combined with cisplatin on transplanted tumor in a nude mice model. The result showed that the combination of decitabine and cisplatin significantly inhibited tumor growth. Meantime, decitabine and cisplatin could be synergistic to reverse the DNA methylation, and mRNA, protein expression level of Sox2. However, further

Table 8 The Effect of Different Treatments on Sox2 Protein Expression Level in a Nude Mice Model

\begin{tabular}{|l|l|l|}
\hline Group & $\begin{array}{l}\text { Sox2 mRNA/ } \\
\text { GAPDH mRNA }\end{array}$ & P-value \\
\hline Control group & $0.08 \pm 0.04$ & \\
$5 \mathrm{mg} / \mathrm{kg}$ emcitabine & $0.30 \pm 0.09$ & $<0.0 \mathrm{I}$ \\
$6 \mathrm{mg} / \mathrm{kg}$ isplatin & $0.13 \pm 0.06$ & $>0.05$ \\
$5 \mathrm{mg} / \mathrm{kg}$ emcitabine $+6 \mathrm{mg} / \mathrm{kg}$ & $0.95 \pm 0.14$ & $<0.01$ \\
emcitabine & & \\
\hline
\end{tabular}


clinical trials should be carried out to prove the clinical value of decitabine combined with cisplatin on patients with GC.

\section{Conclusion}

Cisplatin and decitabine could be synergistic to induce Sox2 DNA demethylation to promote re-expression of the Sox 2 gene, which exerts an anti-tumor effect on GC. It may suggest an insight for innovative therapeutics of GC.

\section{Statement of Ethics}

This study and all experimental protocols were approved by the Animal Care and Use Committee of Xiamen University and carried out in accordance with the guidelines of the Animal Care and Use Committee of Xiamen University. The SGC-823 cell was approved by the ethics committee of the Ethics Committee of the First Affiliated Hospital of Xiamen University and BGC-823 cells were authenticated by STR profile. The human tissue samples were approved by the ethics committee of the First Affiliated Hospital of Xiamen University, and written informed consent was obtained from the patients (Approval number [KYH 2019-044]).

\section{Acknowledgments}

We would like to thank everyone who helped with this study. This work was supported by Xiamen Scientific and Technological Plan (No. 3502Z20194005, 3502Z20184020).

\section{Disclosure}

The authors report no conflicts of interest in this work.

\section{References}

1. Karimi P, Islami F, Anandasabapathy S, Freedman ND, Kamangar F. Gastric cancer: descriptive epidemiology, risk factors, screening, and prevention. Cancer Epidemiol Biomarkers Prev. 2014;23(5):700-713. doi:10.1158/1055-9965.EPI-13-1057

2. Ajani JA, Lee J, Sano T, Janjigian YY, Fan D, Song S. Gastric adenocarcinoma. Nat Rev Dis Primers. 2017;3(1):17036. doi:10.1038/nrdp.2017.36

3. Toiyama Y, Okugawa Y, Goel A. DNA methylation and microRNA biomarkers for noninvasive detection of gastric and colorectal cancer. Biochem Biophys Res Commun. 2014;455(1-2):43-57. doi:10.1016/j. bbrc.2014.08.001

4. Li L, Ying J, Li H, et al. The human cadherin 11 is a pro-apoptotic tumor suppressor modulating cell stemness through Wnt/beta-catenin signaling and silenced in common carcinomas. Oncogene. 2012;31 (34):3901-3912. doi:10.1038/onc.2011.541

5. Esteller M, Fraga MF, Guo M, et al. DNA methylation patterns in hereditary human cancers mimic sporadic tumorigenesis. Hum Mol Genet. 2001;10(26):3001-3007. doi:10.1093/hmg/10.26.3001

6. Esteller M, Corn PG, Baylin SB, Herman JG. A gene hypermethylation profile of human cancer. Cancer Res. 2001;61(8):3225-3229.
7. Tsukamoto T, Inada $\mathrm{K}$, Tanaka H, et al. Down-regulation of a gastric transcription factor, Sox2, and ectopic expression of intestinal homeobox genes, $\mathrm{Cdx} 1$ and $\mathrm{Cdx} 2$ : inverse correlation during progression from gastric/intestinal-mixed to complete intestinal metaplasia. J Cancer Res Clin Oncol. 2004;130(3):135-145. doi:10.1007/s00432-003-0519-6

8. Tsukamoto T, Mizoshita T, Mihara M, et al. Sox2 expression in human stomach adenocarcinomas with gastric and gastric-andintestinal-mixed phenotypes. Histopathology. 2005;46(6):649-658. doi:10.1111/j.1365-2559.2005.02170.x

9. Hutz K, Mejias-Luque R, Farsakova K, et al. The stem cell factor SOX2 regulates the tumorigenic potential in human gastric cancer cells. Carcinogenesis. 2014;35(4):942-950. doi:10.1093/carcin/ bgt410

10. Tian T, Zhang Y, Wang S, Zhou J, Xu S. Sox2 enhances the tumorigenicity and chemoresistance of cancer stem-like cells derived from gastric cancer. J Biomed Res. 2012;26(5):336-345. doi:10.7555/ JBR.26.20120045

11. Matsuoka J, Yashiro M, Sakurai K, et al. Role of the stemness factors sox2, oct3/4, and nanog in gastric carcinoma. J Surg Res. 2012;174 (1):130-135. doi:10.1016/j.jss.2010.11.903

12. Li XL, Eishi Y, Bai YQ, et al. Expression of the SRY-related HMG box protein SOX2 in human gastric carcinoma. Int J Oncol. 2004;24 (2):257-263.

13. Otsubo T, Akiyama Y, Yanagihara K, Yuasa Y. SOX2 is frequently downregulated in gastric cancers and inhibits cell growth through cell-cycle arrest and apoptosis. Br J Cancer. 2008;98(4):824-831. doi:10.1038/sj.bjc.6604193

14. Otsubo T, Akiyama Y, Hashimoto Y, Shimada S, Goto K, Yuasa Y. MicroRNA-126 inhibits SOX2 expression and contributes to gastric carcinogenesis. PLoS One. 2011;6(1):e16617. doi:10.1371/journal. pone. 0016617

15. Camilo V, Barros R, Sousa S, et al. Helicobacter pylori and the BMP pathway regulate CDX2 and SOX2 expression in gastric cells. Carcinogenesis. 2012;33(10):1985-1992. doi:10.1093/carcin/bgs233

16. Zhang X, Yu H, Yang Y, et al. SOX2 in gastric carcinoma, but not Hath1, is related to patients' clinicopathological features and prognosis. J Gastrointest Surg. 2010;14(8):1220-1226. doi:10.1007/ s11605-010-1246-3

17. Wang S, Tie J, Wang R, et al. SOX2, a predictor of survival in gastric cancer, inhibits cell proliferation and metastasis by regulating PTEN. Cancer Lett. 2015;358(2):210-219. doi:10.1016/j.canlet.2014.12.045

18. Sartorius UA, Krammer PH. Upregulation of Bcl-2 is involved in the mediation of chemotherapy resistance in human small cell lung cancer cell lines. Int J Cancer. 2002;97(5):584-592. doi:10.1002/ijc.10096

19. Helmbach H, Kern MA, Rossmann E, et al. Drug resistance towards etoposide and cisplatin in human melanoma cells is associated with drug-dependent apoptosis deficiency. J Invest Dermatol. 2002;118 (6):923-932. doi:10.1046/j.1523-1747.2002.01786.x

20. Sussman RT, Stanek TJ, Esteso P, Gearhart JD, Knudsen KE, McMahon SB. The epigenetic modifier ubiquitin-specific protease 22 (USP22) regulates embryonic stem cell differentiation via transcriptional repression of sex-determining region Y-box 2 (SOX2). $J$ Biol Chem. 2013;288(33):24234-24246. doi:10.1074/jbc. M113.469783

21. Momparler RL. Epigenetic therapy of non-small cell lung cancer using decitabine (5-aza-2'-deoxycytidine). Front Oncol. 2013;3:188. doi: $10.3389 /$ fonc. 2013.00188

22. Albertus DL, Seder CW, Chen G, et al. AZGP1 autoantibody predicts survival and histone deacetylase inhibitors increase expression in lung adenocarcinoma. $J$ Thorac Oncol. 2008;3(11):1236-1244. doi:10.1097/JTO.0b013e318189f5ec

23. Gravina GL, Marampon F, Di Staso M, et al. 5-Azacitidine restores and amplifies the bicalutamide response on preclinical models of androgen receptor expressing or deficient prostate tumors. Prostate. 2010;70(11):1166-1178. doi:10.1002/pros.21151 
24. Viet CT, Dang D, Achdjian S, Ye Y, Katz SG, Schmidt BL. Decitabine rescues cisplatin resistance in head and neck squamous cell carcinoma. PLoS One. 2014;9(11):e112880. doi:10.1371/journal. pone.0112880

25. Balch C, Yan P, Craft T, et al. Antimitogenic and chemosensitizing effects of the methylation inhibitor zebularine in ovarian cancer. Mol Cancer Ther. 2005;4(10):1505-1514. doi:10.1158/1535-7163.MCT-05-0216

26. Momparler RL. Cancer epigenetics. Oncogene. 2003;22 (42):6479-6483. doi:10.1038/sj.onc.1206774

27. Wei Z, Yang Y, Zhang P, et al. Klf4 interacts directly with Oct4 and Sox2 to promote reprogramming. Stem Cells. 2009;27 (12):2969-2978. doi:10.1002/stem.231

28. van den Berg DL, Snoek T, Mullin NP, et al. An Oct4-centered protein interaction network in embryonic stem cells. Stem Cell. 2010;6(4):369-381. doi:10.1016/j.stem.2010.02.014

29. Driessens G, Blanpain C. Long live sox2: sox2 lasts a lifetime. Stem Cell. 2011;9(4):283-284. doi:10.1016/j.stem.2011.09.007

30. Masui S, Nakatake Y, Toyooka Y, et al. Pluripotency governed by Sox 2 via regulation of Oct3/4 expression in mouse embryonic stem cells. Nat Cell Biol. 2007;9(6):625-635. doi:10.1038/ncb1589

31. Avilion AA, Nicolis SK, Pevny LH, Perez L, Vivian N, Lovell-Badge R. Multipotent cell lineages in early mouse development depend on SOX2 function. Genes Dev. 2003;17(1):126-140. doi:10.1101/gad.224503
32. Wang SQ, Liu J, Qin J, et al. CAMK2A supported tumor initiating cells of lung adenocarcinoma by upregulating SOX2 through EZH2 phosphorylation. Cell Death Dis. 2020;11(6):410. doi:10.1038/ s41419-020-2553-6

33. Rybak AP, Tang D. SOX2 plays a critical role in EGFR-mediated self-renewal of human prostate cancer stem-like cells. Cell Signal. 2013;25(12):2734-2742. doi:10.1016/j.cellsig.2013.08.041

34. Xianglong Tian JZ, Biao L. T-cadherin expression induced by 5-azo2 '-deoxycytidine in nude mouse HepG2 tumor cells and its inhibitory effect on tumor growth. J Shanghai Jiao Tong Univ. 2007;27 (5):533-536.

35. Zhilun Liang ZH, Chen X. T-cadherin expression induced by 5-azo-2 '-deoxycytidine in nude mouse HepG2 tumor cells and its inhibitory effect on tumor growth. World Chin Dig J. 2008;16(16):1741-1745. doi:10.11569/wcjd.v16.i16.1741

36. Plumb JA, Strathdee G, Sludden J, Kaye SB, Brown R. Reversal of drug resistance in human tumor xenografts by 2 '-deoxy-5-azacytidine-induced demethylation of the hMLH1 gene promoter. Cancer Res. 2000;60(21):6039-6044.

\section{Publish your work in this journal}

OncoTargets and Therapy is an international, peer-reviewed, open access journal focusing on the pathological basis of all cancers, potential targets for therapy and treatment protocols employed to improve the management of cancer patients. The journal also focuses on the impact of management programs and new therapeutic agents and protocols on patient perspectives such as quality of life, adherence and satisfaction. The manuscript management system is completely online and includes a very quick and fair peer-review system, which is all easy to use. Visit http://www.dovepress.com/ testimonials.php to read real quotes from published authors. 